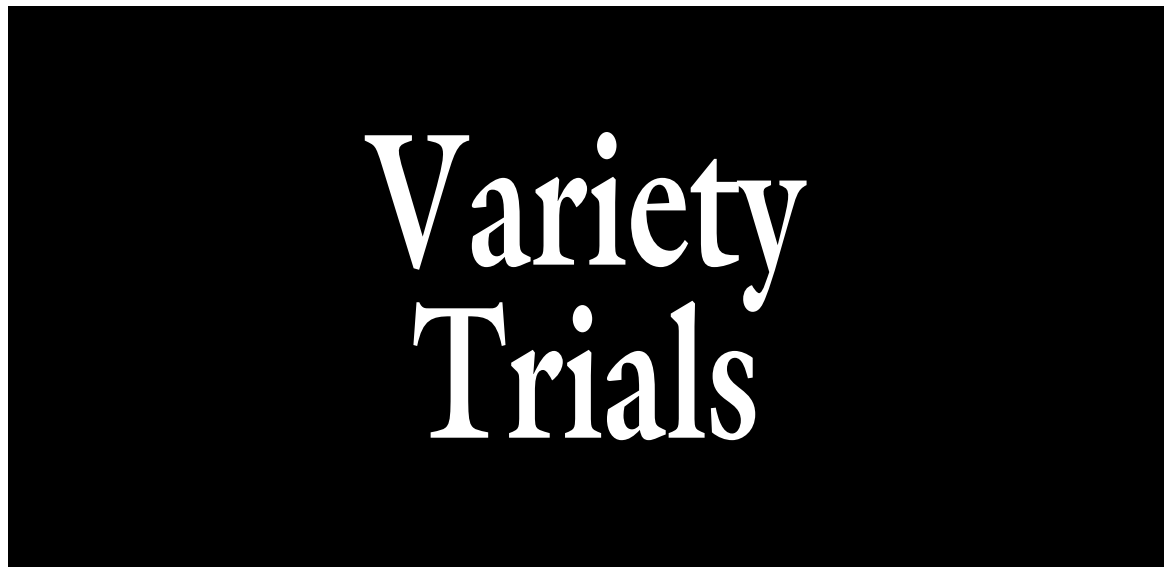

\section{Evaluation of Yardlong Bean as a Potential New Crop for Growers in the Southeastern United States}

\author{
Christine Coker ${ }^{1,3}$, Mike Ely $^{2}$, and Thomas Freeman ${ }^{2}$
}

ADDITIONAL INDEX WORDs. Vigna unguiculata, asparagus bean, varietal superiority, cultivar evaluation, yield

SUMMARY. Ethnicity plays a strong role in niche market development, and the Asian market is currently underserved. As Asian populations continue to grow in Mississippi, especially along the Gulf Coast, it is important to recognize new market opportunities. The fruit and vegetables desired by the diverse Asian population are often unavailable or of poor quality as a result of extensive shipping distances.

Mississippi growers can meet this need for fresh Oriental produce at a higher price than traditional vegetables. Yardlong bean or asparagus bean (Vigna unguiculata ssp. sesquipedalis) is the same species as cowpea. The cultural practices for yardlong bean are similar to that of traditional pole beans (Phaseolus vulgaris). However, there is still much to be learned about this crop in terms of pest management, disease susceptibility, and varietal superiority. The objectives of this research were to compare length and yield of eight yardlong bean varieties and collect observational data regarding production practices. Four replications of eight yardlong bean varieties were grown at Beaumont, MS, during Summer 2001 and 2002. Beans were grown on 4-ft-wide trellises $1 \mathrm{ft}$ above the soil line. Beans were harvested twice per week. Highest marketable yields were attained with the varieties Red Seed and Black Seed, which are best suited for growing conditions in southern Mississippi. However, mosaic viruses may pose a potential production problem, and further research is warranted to determine best cultural practices and pest management. southeast Asian, Chinese, and Filipino cultures. It is a vigorous climbing annual, producing 9- to $12-\mathrm{ft}$ indeterminate vines. The pods hang in pairs that should be picked for vegetable use before maturity. The yardlong bean may be the most vegetable-like of the cowpeas, although several variety classes of cowpea, including pink-eyed pea, black-eyed pea, crowder pea, and cream pea, are widely grown as vegetable crops in the southern United States. There is also extensive production of vegetable-type cowpeas throughout Asia and Africa. Vines are supported on a trellis to prevent pods from contacting the ground and to assure straight pod development. Harvest most often begins $\approx 70 \mathrm{~d}$ after planting and may continue for 25 to $30 \mathrm{~d}$. Pods are 11 to 31 inches long and sometimes longer. The pods are used much like traditional pole beans (Rubatzky and Yamaguchi, 1997; Van Horn and Myers, 2003).

Yardlong beans are day-neutral and tolerate heat and relatively dry conditions better than the pole bean. However, it does require a higher rainfall than the more drought-tolerant black-eyed pea (Purseglove, 1968). Yardlong beans do not have a long shelf life. Decreased postharvest acceptability is the result of high respiration and wilting of the pods. Although low-temperature storage will prolong shelf life, the pods are chilling-sensitive and are injured even after a few days at temperatures below $10{ }^{\circ} \mathrm{C}$ (Rubatzky and Yamaguchi, 1997). Darkening, rusty brown lesions, seed discoloration, and increased susceptibility to decay can occur if pods are stored between 5 and $7.5{ }^{\circ} \mathrm{C}$ (Cantwell and Kasmire, 2002).

Yardlong beans are reported to be disease-susceptible, although less so than pole beans (Martin and Ruberte, 1980). Powdery mildew (Erysipbe spp.) and aphids (Aphididae) have been shown to cause minimal crop damage (Bland and
Approved for publication as Mississippi State University Mississippi Agricultural and Forestry Experiment Station journal article J-11025.

Mention of a trademark, proprietary product, or vendor does not constitute a guarantee of warranty of the product by Mississippi State University and does not imply its approval to the exclusion of other products or vendors that also may be suitable.

${ }^{1}$ Mississippi State University, Coastal Research and Extension Center, 1815 Popps Ferry Road, Biloxi, MS 39532

${ }^{2}$ Mississippi State University, Beaumont Horticultural Unit, Coastal Research and Extension Center, 478 Hwy. 15 N, Beaumont, MS 39423

${ }^{3}$ Corresponding author. E-mail: ccoker@ra.msstate.edu.
$\mathrm{Y}$ ardlong bean, also called chinese long bean or asparagus bean, is the same species as cowpea. The pods are popular in

\begin{tabular}{llll}
\hline $\begin{array}{l}\text { Units } \\
\text { To convert U.S. to SI, } \\
\text { multiply by }\end{array}$ & U.S. unit & SI unit & $\begin{array}{l}\text { To convert SI to U.S., } \\
\text { multiply by }\end{array}$ \\
\hline 0.3048 & $\mathrm{ft}$ & $\mathrm{m}$ & 3.2808 \\
2.5400 & inch $(\mathrm{es})$ & $\mathrm{cm}$ & 0.3937 \\
0.4536 & $\mathrm{lb}$ & $\mathrm{kg}$ & 2.2046 \\
1.1209 & $\mathrm{lb} / \mathrm{acre}$ & $\mathrm{kg} \cdot \mathrm{ha}^{-1}$ & 0.8922 \\
$\left({ }^{\circ} \mathrm{F}-32\right) \div 1.8$ & ${ }^{\circ} \mathrm{F}$ & ${ }^{\circ} \mathrm{C}$ & $\left(1.8 \times{ }^{\circ} \mathrm{C}\right)+32$
\end{tabular}


Knausenberger, 1985). Yardlong beans may also be susceptible to root knot nematode (Meloidogyne spp.) infestation. In studies by Rhoden et al. (1990a, 1990b), root knot nematodes resulted in reduced seed yield and decreased pod production. Plant dry weight was also significantly reduced by this infestation.

Yardlong beans are a significant source of nutrition. The U.S. Department of Agriculture (2005) reported that yardlong beans are a good source of both vitamins $\mathrm{A}$ and $\mathrm{C}$, providing $17 \%$ and $31 \%$ of the recommended daily allowance for these vitamins, respectively.

The objectives of this research were to compare length and yield of eight yardlong bean varieties and collect observational data regarding production practices.

\section{Materials and methods}

Eight varieties of yardlong bean seeds (Evergreen Seeds, Anaheim, CA) were planted on 27 June 2001 and 21 May 2002 at the Mississippi State University, Coastal Research and Extension Center, Beaumont Horticultural Unit in Beaumont on McLaurin sandy loam. Seeds were sown on 36-inch black plastic mulched beds set at 4 -inch spacing in 2001 and 6-inch spacing in 2002 . There were $6 \mathrm{ft}$ between rows. There were four 20 -ft-long replications of each variety. Irrigation was supplied as needed through drip tape. Preplant fertilizer was applied according to soil test recommendations as $400 \mathrm{lb} /$ acre $5 \mathrm{~N}-6.5 \mathrm{P}-24.9 \mathrm{~K}$ plus $20 \mathrm{lb} /$ acre $\mathrm{N}$ in 2001 and $65 \mathrm{lb} /$ acre $\mathrm{N}$ in 2002 . Plants were fertigated with $1.5 \mathrm{lb}$ calcium nitrate per $100 \mathrm{ft}$ of row at fruit set. Plants were trained to climb 4-ft-wide plastic trellis (Hummert International, Earth City, MO) set $\mathrm{l} \mathrm{ft}$ above the soil line. Entire plots were harvested. There were 12 harvests in 2001 beginning on 20 Aug. 2001 and ending on 1 Oct. 2001. In 2002 , beans were harvested 11 times beginning on 11 July and ending on 19 Aug.

Leafminers (Liriomyza sativae) and silverleaf whiteflies (Bemisia argentifolii) were present in 2001 and were controlled with diazinon at label rates. Follow up applications of diazinon and carbaryl (Sevin; GardenTech, Lexington, KY) were applied to further control leafminers. In 2002, two applications of esfenvalerate (DuPont Agricultural Products, Wilmington, DE) were applied to control insect pests. Chlorothalonil fungicides (Syngenta, Greensboro, NC, in 2001 and Sipcam Agro USA, Inc., Roswell, GA, in 2002) were applied following commercial production practices. Metachlor (Syngenta) was applied to control weeds in both seasons.

Total yield was determined by total weight of the entire plot. Marketable pods were immature without expanded seeds. The pod was smooth with few or no blemishes. Culls included dry, damaged, and diseased pods. Average length was determined by measuring eight pods per variety per replication. Data were analyzed using analysis of variance and means were separated with Duncan's multiple range test at the $5 \%$ level.

\section{Results and discussion}

PoD CHARACTERIsTICS. Each yardlong bean variety exhibited unique characteristics (Table 1). For instance, 'Canton White Pod' had a very light green pod with a red seed with a white eye. 'Red Stripe Seed' and 'Black Stripe Seed' exhibited seedcoat colorations as indicated by their names.

Eight pods per variety per replication were measured and averaged at maturity. On average, pods of each variety were shorter in 2001 than 2002 (Table 2). 'Canton White Pod' and 'White Seed' had the shortest pods in 2001 measuring 15.0 and 15.6 inches, respectively. 'Black Stripe Seed' yielded the longest pods in 2001, averaging 21.2 inches.

In 2002, 'Orient Extra Long' yielded the longest pods averaging 23.2 inches followed closely by 'Black Seed' and 'Red Seed', each of which averaged 21.3 inches. However, there was no significant difference among the three varieties. 'Kaohsiung' yielded the shortest pods with an average length of 15.9 inches. 'Red Stripe Seed' and 'Canton White Pod' followed closely with average lengths of 17.1 and 17.6 inches, respectively.

YIELD. Marketable yields ranged from 11,476 lb/acre for 'Canton White Pod' to $17,244 \mathrm{lb} /$ acre for 'Red Seed' in 2001 (Table 2). 'Red Seed' and 'Black Seed' yielded

Table 1. Descriptions of eight yardlong bean varieties grown at the Beaumont Horticultural Unit, Beaumont, MS, in 2001 and 2002.

\begin{tabular}{ll}
\hline Variety & \multicolumn{1}{c}{ Description } \\
\hline Black Seed & Dark green pods with firm texture; dark black seeds \\
Red Seed & Dark green pods; small seed cavity with red seed \\
Canton White Pod & Very light green pods; red seed with white eyes \\
Kaohsiung & Dark green, thick pods; black seed \\
Red Stripe Seed & Light green pods; red stripe on seed \\
Black Stripe Seed & Light green pods; dark brown seed with black stripe \\
White Seed & Light green pods; white seed \\
Orient Extra Long & Dark green pods; black seed
\end{tabular}

Table 2. Average length and marketable yield of yardlong bean varieties grown at the Beaumont Horticultural Unit in Beaumont, MS, in 2001 and 2002.

\begin{tabular}{lccccc}
\hline & \multicolumn{2}{c}{ Avg. length (inches) $)^{\mathrm{z}}$} & & \multicolumn{2}{c}{ Marketable yield (lb/acre) } \\
\cline { 2 - 3 } Variety & $\mathbf{2 0 0 1}$ & $\mathbf{2 0 0 2}$ & & $\mathbf{2 0 0 1}$ & $\mathbf{2 0 0 2}$ \\
\hline Black Seed & $18.4 \mathrm{c}^{\mathrm{y}}$ & $21.3 \mathrm{a}$ & & $16,291 \mathrm{a}$ & $25,224 \mathrm{a}$ \\
Red Seed & $19.8 \mathrm{~b}$ & $21.3 \mathrm{a}$ & & $17,244 \mathrm{a}$ & $15,927 \mathrm{bcd}$ \\
Canton White Pod & $15.0 \mathrm{e}$ & $17.6 \mathrm{~cd}$ & & $11,476 \mathrm{~b}$ & $17,866 \mathrm{bc}$ \\
Black Stripe Seed & $21.2 \mathrm{a}$ & $18.6 \mathrm{bc}$ & & $11,995 \mathrm{~b}$ & $14,451 \mathrm{~cd}$ \\
Kaohsiung & $17.1 \mathrm{~d}$ & $15.9 \mathrm{~d}$ & & $9,512 \mathrm{~b}$ & $11,741 \mathrm{~d}$ \\
White Seed & $15.6 \mathrm{e}$ & $20.7 \mathrm{ab}$ & $9,605 \mathrm{~b}$ & $18,438 \mathrm{bc}$ \\
Red Stripe Seed & $19.7 \mathrm{~b}$ & $17.1 \mathrm{~cd}$ & $9,137 \mathrm{~b}$ & $18,077 \mathrm{bc}$ \\
Orient Extra & $16.7 \mathrm{~d}$ & $23.2 \mathrm{a}$ & & $11,750 \mathrm{~b}$ & $21,344 \mathrm{ab}$
\end{tabular}

Long

${ }^{\mathrm{z}} \mathrm{l}$ inch $=2.54 \mathrm{~cm}, \mathrm{l} \mathrm{lb} /$ acre $=1.1209 \mathrm{~kg} \cdot \mathrm{ha}^{-1}$

${ }^{y}$ Means within columns followed by different letters are significantly different according to Duncan's multiple range test at the $5 \%$ level. 
significantly more marketable pods than the other six varieties, yielding 17,244 and 16,291 lb/acre, respectively. Yields were statistically similar for all other varieties.

There was more variation in the 2002 trial. 'Kaohsiung' yielded the least marketable pods with a yield of only $11,741 \mathrm{lb} /$ acre. 'Black Seed' performed well with a marketable yield of $25,224 \mathrm{lb} /$ acre. However, this was not significantly greater than that of 'Orient Extra Long', which yielded $21,344 \mathrm{lb} /$ acre.

Average percent of total yield that were culls was $28 \%$ and $26 \%$ in 2001 and 2002, respectively. In 2001, varieties 'Red Seed', 'Black Stripe Seed', and 'Kaoshiung', although similar to one another, had significantly more culls than the other varieties. Culls for the three varieties were 6824, 4195, and $4127 \mathrm{lb} / \mathrm{acre}$, respectively. In 2002, 'Black Seed' had significantly more culls than the others with $7936 \mathrm{lb} /$ acre.

Several factors may have contributed to the increased success in the 2002 season. Insect pressure was much greater in the 2001 growing season. Leafminers and whiteflies were present concurrently before fruit set. In 2002, insecticide was applied as a preventative based on 2001 experiences. Growing conditions in Mississippi are hot and humid. Because of this, susceptible crops may be more vulnerable to disease pressure. The other major difference between seasons was planting date. Seeds were sown 5 weeks earlier in 2002. Increased air and soil temperatures may have affected yields. Therefore, it is recommended that growers plant yardlong beans no later than May in the southern United States for optimal yields.

Poor postharvest quality was observed within just a few days of harvest regardless of chilling or handling. This is in agreement with the observations of Rubatzky and Yamaguchi (1997). Further research is warranted to evaluate disease and pest susceptibility as well as optimal postharvest handling of yardlong bean in the southeastern United States.

Yardlong beans are produced primarily in Mexico and the Caribbean, although some commercial production is present in California. As growers continue to search for diversity in their production to increase profits and reduce risk, Asian vegetable crops present an opportunity to diversify without changing production practices. Asian populations of the far southern United States continue to flourish, and growers should seize the opportunity to serve this market niche.

\section{Literature cited}

Bland, R.G. and W.I. Knausenberger. 1985. Predators and parasites of insect pests on cantaloupe and asparagus bean, St. Croix, U.S. Virgin Islands, Proc. Caribbean Food Crops Soc. Annu. Mtg, p. 56-60.

Cantwell, M.I. and R.F. Kasmire. 2002. Postharvest handling systems: Fruit vegetables, p. 407-421. In: A.A. Kader (ed.). Postharvest technology of horticultural crops. 3rd ed. University of California,
Agriculture and Natural Resources Publ. 3311. Davis.

Martin, F.W. and R.M. Ruberte. 1980. Techniques and plants for the tropical subsistence farm. U.S. Department of Agriculture, Agriculture Review and Manual S-8.

Purseglove, J. 1968. Tropical crops. Dicotyledons. Longman, London, UK.

Rhoden, E.G., C.K. Bonsi, and M.L. Ngoyi. 1990a. Effect of southern root knot nematode on yield components of yardlong beans, p. 446 (Abstr.). In: J. Janick and J.E. Simon (eds.). Advances in new crops: Proceedings of the First National Symposium on New Crops, Research, Development, Economics. Timber Press, Portland, OR.

Rhoden, E.G., C.K. Bonsi, and M.L. Ngoyi. 1990b. Susceptibility of yardlong beans to root knot nematode infestation, p. 446 (Abstr.). In: J. Janick and J.E. Simon (eds.). Advances in new crops: Proceedings of the First National Symposium on New Crops, Research, Development, Economics. Timber Press, Portland, OR.

Rubatzky, V.E. and M. Yamaguchi. 1997. World vegetables: Principles, production, and nutritive values. Chapman and Hall, New York.

U.S. Department of Agriculture. 2005. National nutrient database for standard reference, release 18. 19 Sept. 2006. <http://www.nal.usda.gov/fnic/ foodcomp/cgi-bin/measure.pl $>$.

Van Horn, M. and C. Myers. 2003. Chinese long bean, yard-long bean, asparagus bean. 7 Apr. 2003. <http://www. rain.org/greennet/docs/exoticveggies/ html/chineselongbeans.html . 